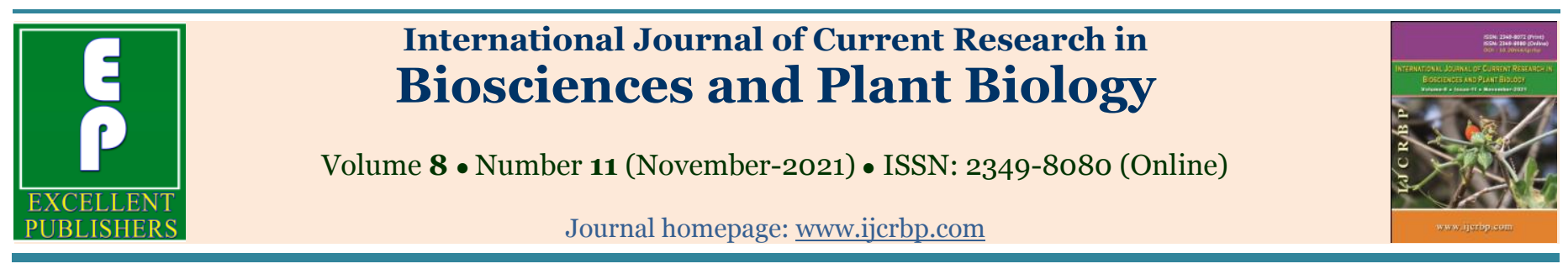

Review Article

doi: $\underline{\text { https://doi.org/10.20546/ijcrbp.2021.811.004 }}$

\title{
Microbiomes of medicinal plants and their potential avenues as bioresources - A review
}

\author{
Rehma Rizwan $(\mathbb{D} *$, Ragini Gothalwal \\ Department of Biotechnology, Barkatullah University, Bhopal - 462 026, Madhya Pradesh, India \\ *Corresponding author; e-mail: rehmarizwan@gmail.com
}

\section{Article Info}

Keywords:

Holobiont

Inter-relationship

Medicinal plant

Phytotherapeutic

Abstract

Sustainable enhancement in bioactive production of medicinal plants must encompass a balanced use of inorganic, organic, and biofertilizer sources of plant nutrients to augment and maintain soil fertility, productivity and quantity. This necessitates an intricate analysis of the inter-relationships between microbial communities and their impact on host plant productivity. A large variety of fungi and bacteria is recognized in phyllosphere, endosphere and rhizosphere of medicinal plant that showed significant effect in secondary metabolite alteration and uptake of plant nutrients. Significant phytotherapeutic compounds are actually produced by associated microbes through interaction with their host plant which lead to recognition of microbe and plant interaction. In modern medicine and agriculture, medicinal plant are considered rich bioresources yet their ecological role of microbiome is unexplored. Plant-associated microbes form holobiont which is responsible for the beneficial interplay of the host and its microbiome by maintaining host plant fitness, health, nutrition and increased tolerance to abiotic stresses, adaptation to environmental variations promotion of the establishment of mycorrhizal association. Some genera are ubiquitous and can be found distributed over the entire plant, such as the well-known plant-associated genera Bacillus and Pseudomonas. The objective of this review is to introduce insights into plant-microbe interaction in medicinal plants.
\end{abstract}

- Received: 05 September 2021 • Revised: 24 October 2021 • Accepted: 30 October 2021 • Published Online: 06 November 2021

\section{Introduction}

Phytotherapeutic compounds are actually produced by associated microbes or through interaction with their host, medicinal plant research primarily focused on bioactive phytochemicals, however, the focus is currently shifting due to the recognition in modern medicine and agriculture. Medicinal plants provide an enormous bioresources of potential use, yet their microbiome is largely unknown. It has been concluded that the effect of long-term cultivation of medicinal and aromatic plants (MAPs) on microbial diversity, which may affect soil health and productivity. This information will help to identify good agricultural practices that could restore the state shift, minimizing loss in soil health and maintaining ecosystem functionality and environmental sustainability (Misra et al., 2019).

Plants live in association with microbes in both above and below ground parts, as some are beneficial and some are harmful to the plant. Microbes which are 
found in the phyllosphere, endosphere and rhizosphere, can have beneficial, neutral, or detrimental effects on plant health and development (Köberl et al., 2013). Several works have been done on plant-microbe interactions and microbial diversity of the rhizospheric region of medicinal plants. The biogeochemical reactions and plant metabolism influence by the plant secondary metabolite and root exudates which include various sugars and organic acids. Signalling molecules like strigolactones induce the colonisation of the mycorrhiza fungi with plant roots and stimulate the germination of the parasitic plant. Leguminous roots secreted flavonoids thus increase the growth of symbiotic and non symbiotic nitrogen-fixing bacteria similarly and also attract pathogenic oomycetes as well. Hence, plant growth enhanced by root-associated microflora and endophytes (fungi or bacteria) due to the secretion of phytohormone (auxin/cytokinin) and nutrients like phosphorus, nitrogen, and iron. Microbial association with roots may induce plant resistance against the several biotic and abiotic stresses, such as toxic metals, pathogens, drought, high temperature, saline soils, adverse soil $\mathrm{pH}$, and transplant shock. In the era of next-generation sequencing, studying the plantmicrobe interaction opens a new way to understand their association as well as help in improvement of sustainable agriculture by plant growth and improve crop yield. Enhancement of secondary metabolites in medicinal plant by exploration of rhizospheric microbes in the future for might be a new vista opened for sustainable agriculture practices. In this review we will focus our attention to the role of medicinal plantmicrobe interaction derived ingredients.

\section{Plant-microbe associated bioactive compounds}

The significant numbers of natural products are actually produced by microbes and microbial interactions with the host from where they were isolated, and for several medicinal plants it's presumed that the plantassociated microbiome, especially the complex community of the endomicrobiome, is directly or indirectly involved within the production of bioactive phytochemicals. Presently, however, only a little subset of potential microbial strains might be definitively attributed to phytotherapeutic properties (Strobel et al., 2002; Strobel and Daisy, 2003; Miller et al., 2012a; Miller et al., 2012b) and their relative contribution to the recognized valuable bioactivity of medicinal plants isn't clear as of yet.
For centuries, several phytotherapeutics have also been known for their anti-inflammatory features, yet despite the progress within medical research, chronic inflammatory diseases such as asthma, arthritis, and rheumatism remain one of the world's leading health problems (Newman and Cragg, 2012). Hence, nature must still harbor plenty of currently unknown active agents that may serve as leads and scaffolds for the development of efficacious drugs needed for a multitude of diseases (Earanna, 2001). Today, globalization has also had an impact on the use of medicinal plants and has proven beneficial in allowing greater access to these medicines for people all across the globe. For example, TCM plants are very popular in Europe, whereas In India has the unique characteristic of having different well-acknowledged traditional systems of medicine, such as Ayurveda, Siddha, Unani, Yoga, naturopathy, and homeopathy. Growth, quality, and health of the medicinal plants are highly influenced and controlled by their microbiota through microbial metabolisms and host interactions.

\section{Plant growth promotion and biological control plant pathogens}

Many researchers reported application of PGPR enhanced yield of essential oil and secondary metabolites in many medicinal plants, i.e. Phyllanthus amarus, Withania somnifera, Mentha piperita, Solanum viarum and Ocimum basilicum (Glass et al., 2002; Kaymak et al., 2008; Selvaraj et al., 2008; Hemashenpagam and Selvaraj, 2011; Ordookhani et al., 2011; Abdullah et al., 2012). Therefore, the use of microbial associations for medicinal plants provides a sustainable approach to improving crop quality and yield. The importance of PGPR on maintaining soil fertility is well studied by many scientists (Das and Singh, 2014; Parewa et al., 2014a; Mantelin and Touraine, 2004). Hemashenpagam and Selvaraj (2011) had reported in a study inoculation of seeds with PGPR significantly increased the values of available $P$, microbial population, acid phosphatase, alkaline phosphatase, dehydrogenase activity in soil and yields over uninoculated seeds. PGPR communities affect directly or indirectly the plant physiology, nutritional and physicochemical properties of rhizospheric soils through their metabolic activities. They are important components of integrated farming, which help to nourish the crops through required nutrients. Thus, PGPR helps to improve the soil health and increase crop production by fixing atmospheric nitrogen, solubilize 
and mobilize phosphorus, translocate minor elements like $\mathrm{Mo}, \mathrm{Zn}, \mathrm{Cu}$, etc. to the plants, produce plant growth-promoting hormones like IAA and GA and improve soil structure by production of polysaccharides, Uptake of nutrient elements like $\mathrm{Ca}, \mathrm{K}, \mathrm{Fe}, \mathrm{Cu}, \mathrm{Mn}$ and $\mathrm{Zn}$ through proton pump ATPase has been increased by PGPR (Bandopadhyay, 2015).

Fungal diseases are the major constraints in the profitable cultivation of medicinal plants. Phytopathogenic problem of medicinal plants not only reduces the yield, but it is also responsible for the deterioration of biochemical and secondary metabolites which are of immense therapeutic value. Imprudent use of insecticides, fungicides, agrochemicals, and fertilizers poses serious threat to the environment. In the present scenario, rhizospheric microbes (biocontrol agents) have gained popularity due to their effectiveness, safety, and eco-friendliness, and hence their demand has gradually increased. The mechanisms of plant disease management such as mycoparasitism, antibiosis, induced systemic resistance, plant growth promotion, root colonization, siderophore production, phosphate solubilization, etc., have been studied well in reference to medicinal plants. Still due to the distinct features of medicinal plants, future research could be a major breakthrough in the significant increase in the production of medicinal plants. Usage of fungicides is not recommended as it is neither economical nor environmentally friendly. Moreover, its long-term use can cause the development of resistant strains of a pathogen (Ashraf and Zuhaib, 2014a; Ashraf and Zuhaib, 2014b) However, research on biological control gained momentum in the last quarter of the tenth century, and several books (Cook and Baker, 1983; Mukerji, 2000) and review articles have come up stressing the potential of microorganisms in disease management. Numerous microorganisms have been reported to cause antagonism against plant pathogenic fungi in laboratory and in vivo conditions. A perfect biocontrol agent/rhizosphere microbe must have the subsequent qualities.

- Prolonged survival, either in active or passive form.

- Greater probability of contact with the pathogen.

- Functional under variable environments.

- Mass multiplication should be easy, feasible, and economical.

- Proficient and cheap.

- Eco-friendly.
A number of rhizospheric microbes such as Trichoderma, Bacillus, and Pseudomonas have been found successful against a number of important fungal diseases of medicinal plants (Benítez et al., 2004; Strashnov et al., 1985; Kaur et al., 2006; Dubey et al., 2007; Abo-Elyousr et al., 2014). The most common species of Trichoderma which have been successfully exploited in biological control of pathogenic fungi are $T$. virens, T. viride, and T. harzianum (Kumar et al., 2011) T. harzianum and $T$. viride are being used as commercial products for the control of plant diseases. Moreover, Trichoderma can even stimulate plant growth; reports of which have been found in the case of T. virens (Chet et al., 1997) and the stimulation of plant defense mechanisms (Sharma and Gothalwal, 2010). Latha et al., (2009) isolated a strain of $T$. viride with high antagonistic potential against $R$. solani and $S$. rolfsii from soil. It was formulated in talcum powder as a biofungicid. $T$. viride has been found to significantly reduce mycelial growth, a formation of spores, and germ tube formation of $A$. solani and $A$. alternate (Sharma and Trivedi, 2010) T. harzianum has been found active against $F$. oxysporum inciting wilt in Ashwagandha (Harman, 2006).

Mechanism of disease suppression by rhizospheric microbes Trichoderma spp. is reported to suppress plant pathogenic fungi through a combination of different mechanisms such as mycoparasitism, synthesis of antibiotics (Harman et al., 2004) (Jayalakshmi et al., 2009) enzymes degrading cell wall (Zimand et al., 1996) contesting for the availability of important nutrients and increase in plant health (Komatsu, 1968), parasitism of host fungus (Gao et al., 2001; Sriram et al., 2009), inducing plant defense (Zimand et al., 1996), and/or induced systemic resistance (Jayalakshmi et al., 2009) (Handelsman and Stabb, 1996). Most of the biocontrol agents including Trichoderma, Pseudomonas spp., and Bacillus species produce several types of antibiotics (Chet et al., 1997; Vinale et al., 2014). The antibiotics produced by Trichoderma species include gliotoxin (Vinale et al., 2014), harzianic acid (McAlees and Taylor, 1995), trichoviridin (Zafari et al., 2008), viridian (Phuwapraisirisan et al., 2006), viridiol (Aidemark et al., 2010), alamethicin (Goulard et al., 1995), and others (Howell et al., 1983). Gliovirin an antibiotic isolated from Trichoderma (Gliocladium) virens shows a strong inhibitory effect against Pythium ultimum and Phytophthora species (Sharma and Gothalwal, 2020). Thielaviopsis basicola, Phymatotrichum omnivorum, Rhizopus arrhizus, or 
Verticillium dahliae. B. thuringiensis was not inhibited by gliovirin. Secretion of $T$. harzianum strain against Gaeumannomyces graminis exhibited inhibitory effects supporting the fact that bioagent synthesizes antibiotics plays a vital role in the inhibition of the pathogen. Research on the mechanisms responsible for the biocontrol exerted by Trichoderma on phytopathogenic fungi has led to a better understanding of mechanisms, as well as to the isolation of several genes encoding either enzymes and structural or regulatory proteins or components of signaling pathways that are involved in processes such as the specific recognition of hosts by Trichoderma strains (Weller, 1988).

Bacillus and Pseudomonas species are also effective microbes in managing plant diseases by the production of antibiotics (Chet et al., 1997; Whistler et al., 2000). Plant disease suppression due to P. fluorescens may be due to synthesis of pyoluteorin, phenazine, oomycin A, IAA, siderophores, phenazine, siderophore (Schoonbeek et al., 2002; Suzuki et al., 2003; Johri et al., 2003; Rachid and Ahmed, 2005; Siddiqui, 2006) extracellular hydrolytic enzymes (Bagnasco et al., 1998), alginate, HCN (Bagnasco et al., 1998) and pseudomonic acid.

The antimicrobial compounds discussed above are responsible to cause fungistasis, inhibition of spore germination, and degradation of a mycelial wall and also induce other fungicidal effects (Berg and Smalla, 2009) Several microbial inoculants have already been successfully commercialized (Berg et al., 2011; Yang et al., 2018) but a specific biological control strategy for medicinal plants, which are increasingly affected by different soil-borne phytopathogens, has not been available until now. While specific biocontrol agents for medicinal plants are needed, their associated microbiomes with outstanding metabolic activities also provide a promising source for novel BCAs

\section{Impact of environmental factors on phytochemical generation}

Medicinal plants are sessile organisms, they have evolved numerous mechanisms for accommodating changes arising in their fluctuating growth conditions to enable functional flexibility under the influence of environmental factors without affecting cellular and developmental physiological processes (Arnold et al., 2019; Berini et al., 2018) by producing repertoire of secondary metabolites (SMs) that play variety of roles in response to changing environment, growth and development(Kroymann, 2011; Chetri et al., 2013). The changes may be induced by environmental components that include local geo-climatic and seasonal changes, external conditions of temperature, light, humidity and developmental processes, among others, and impact biomass production and biosynthesis of plant secondary metabolites (PSMs) (Ramakrishna and Ravishankar, 2011; Zykin et al., 2018; Ncube and van Staden, 2015). The secondary molecules are produced occasionally in living plant cells and do not play much of significant role in the primary life of plants that produce them, with the production been at low concentration commensurate with growth physiology of a plant species (Edreva et al., 2008). Production of the metabolites by the plants is regarded an adaptive capacity in coping with stressful constraints during challenging and changing environment of growth that may involve production of complex chemical types and interactions in the structural and functional stabilization through signaling processes and pathways (Vashisth et al., 2018). In many recent studies, it had been shown that SM system in plants is a response to the stress and defensive situations that leads to an enhanced biosynthesis of the metabolites in an integrated defense mechanism through dynamic ways (Table 3). However understanding the signaling processes involved and their interconnection with the primary metabolism is yet unclear, and very few had been investigated in some taxonomic groups, based on plant tissues or organs evaluated with rare reports on whole plant system evaluation or cellular levels.

\section{Approach to natural product discovery}

Innovative drug discovery from natural products requires a multidisciplinary approach utilising available and innovative technologies to package such natural product compounds for medical practice and drug development (Fig.1). The successful use of such an approach will allow the development of next-generation drugs to combat the ever-increasing health challenges of today and the future

A systems biology approach coupled with application of available technologies such as genomics, transcriptomics, proteomics, metabolomics/ metabonomics, automation and computational strategies will potentially pave the way for innovative drug design leading to better drug candidates. 
Table 1. Plant-microbe interaction derived bioactive compound from below and above ground regions.

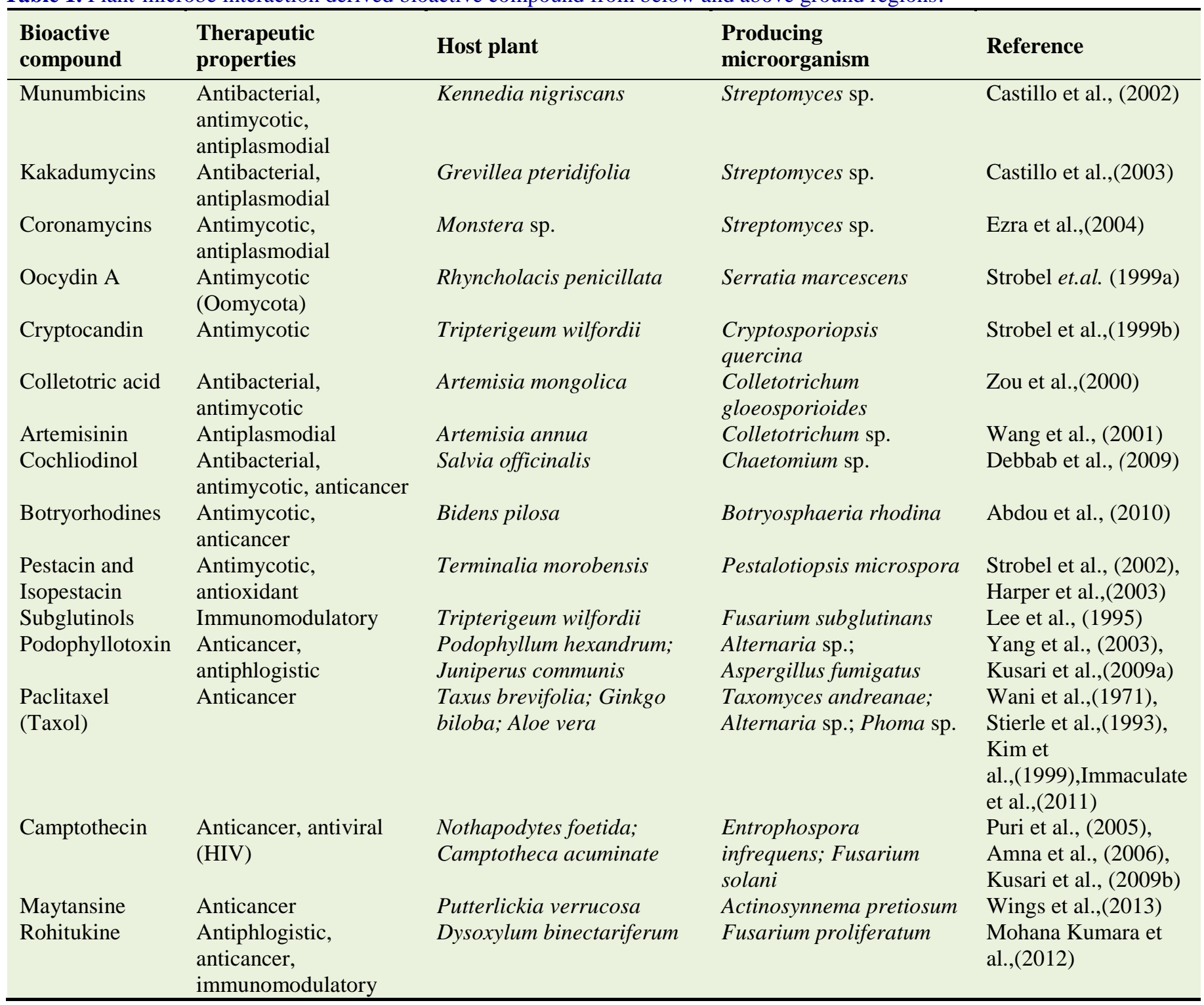

Table 2. Plant growth promoting microorganisms of medicinal plant and their mode of action.

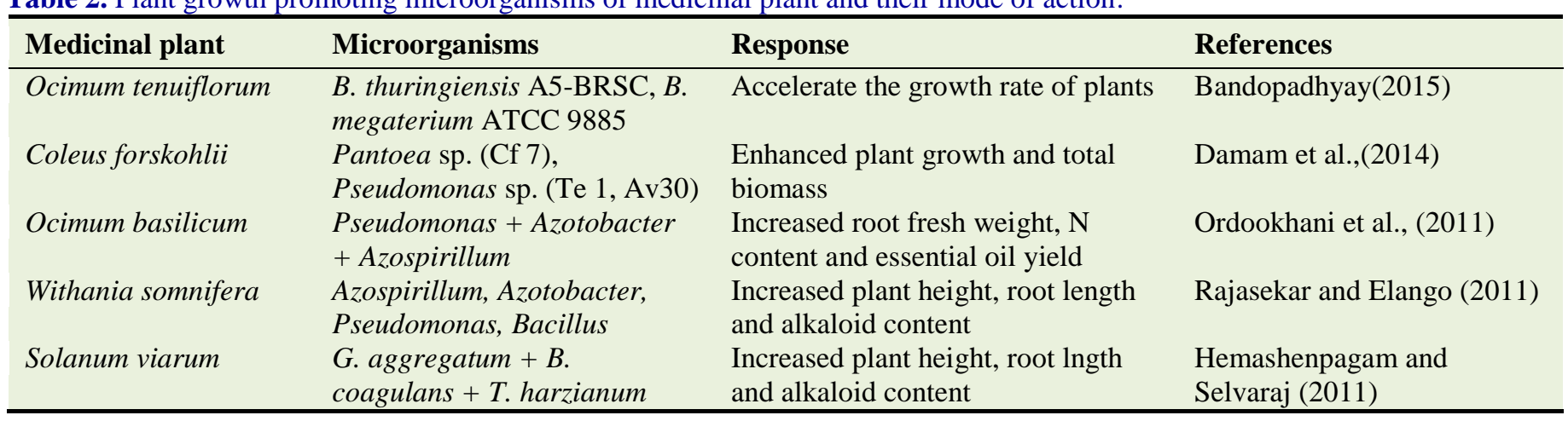


Table 3. Production of some plant secondary metabolites under various in vivo growth conditions of plants.

\begin{tabular}{|c|c|c|c|c|}
\hline $\begin{array}{l}\text { Secondary } \\
\text { metabolite }\end{array}$ & Plant source & Tissue analyzed & Growth condition & References \\
\hline Artemisinin & Artemesia аппиа & $\begin{array}{l}\text { Whole seedling (treated } \\
\text { and control) }\end{array}$ & $\begin{array}{l}\text { Salt, drought and water } \\
\text { logging }\end{array}$ & Vashisth et al. (2018) \\
\hline Camptothecin & $\begin{array}{l}\text { Camptotheca } \\
\text { acuminata }\end{array}$ & Seedlings & $\begin{array}{l}\text { Nitrogen, drought and } \\
\text { anti-transpiration agents }\end{array}$ & $\begin{array}{l}\text { Feng et al.(2002); Sun et al. } \\
(2008)\end{array}$ \\
\hline Codeine & $\begin{array}{l}\text { Papaver } \\
\text { somniferum }\end{array}$ & Plantlets & Drought stress & Szabo et al.(2003) \\
\hline Rohitukine & $\begin{array}{l}\text { Dysoxylum } \\
\text { binectariferum }\end{array}$ & $\begin{array}{l}\text { Seedling (roots, collar } \\
\text { region of stem and } \\
\text { young leaves) }\end{array}$ & Normal & Kumara et al. (2016) \\
\hline Stevioside & Stevia rebaudiana & Leaves (dried) & $\begin{array}{l}\text { Hydroponic culture, salt } \\
\text { stress }\end{array}$ & $\begin{array}{l}\text { Zeng et al. (2013); Srivastava } \\
\text { et al. (2014); Shahverdi et al. } \\
\text { (2015) }\end{array}$ \\
\hline Allicin & Allium sativum & Whole plant & $\begin{array}{l}\text { Pot experiment on light } \\
\text { effect }\end{array}$ & Jeong et al. (2013) \\
\hline Andrographolide & $\begin{array}{l}\text { Andrographis } \\
\text { paniculata }\end{array}$ & Leaves and stem & $\begin{array}{l}\text { Open field experiment } \\
\text { with plant populations }\end{array}$ & Saravanan et al. (2009) \\
\hline Betalain pigments & $\begin{array}{l}\text { Caryophyllales } \\
\text { members }\end{array}$ & Different plant parts & $\begin{array}{l}\text { Different growth } \\
\text { condition }\end{array}$ & Polturak et al. (2018) \\
\hline Saikosaponins & $\begin{array}{l}\text { Bupleurum } \\
\text { chinense }\end{array}$ & 1-year-old plants, plants & $\begin{array}{l}\text { Drought, watering and } \\
\text { re-watering, fertilization }\end{array}$ & Zhu et al. (2009) \\
\hline Sennosides & $\begin{array}{l}\text { Cassia } \\
\text { augustifolia }\end{array}$ & $\begin{array}{l}\text { Pre-, post and flowering } \\
\text { plants }\end{array}$ & Pot culture experiment & Arshi et al. (2006 ) \\
\hline Indole alkaloids & $\begin{array}{l}\text { Catharanthus } \\
\text { roseous }\end{array}$ & Leaves & $\begin{array}{l}\text { Greenhouse under } \\
\text { binary stress-induced } \\
\text { condition }\end{array}$ & Zhu et al. (2015) \\
\hline $\begin{array}{l}\text { Asiaticoside and } \\
\text { madecassoside }\end{array}$ & Centella asiatica & Leaves (post-harvest) & $\begin{array}{l}\text { Low temperature and } \\
\text { water dehydration }\end{array}$ & Plengmuankhae et al. (2015) \\
\hline Valepotriates & Valeria species & All organs & $\begin{array}{l}\text { Normal growth } \\
\text { condition (Iran) }\end{array}$ & Hassan et al. (2008) \\
\hline Rutin & $\begin{array}{l}\text { Dimorphandra } \\
\text { mollis }\end{array}$ & $\begin{array}{l}\text { All plant parts at } \\
\text { different growth stages }\end{array}$ & $\begin{array}{l}\text { Normal, drought, } \\
\text { flooding and salinity }\end{array}$ & Lucci et al. (2009) \\
\hline
\end{tabular}

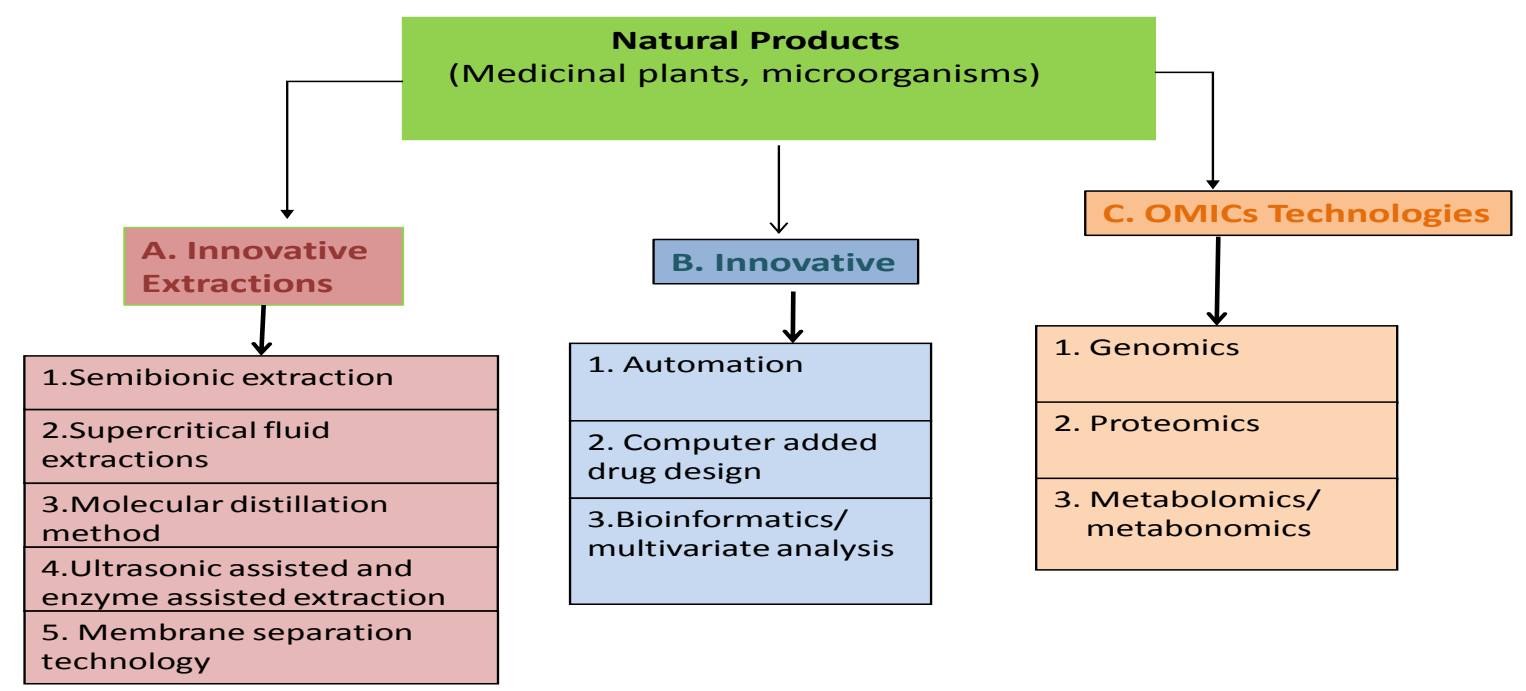

Fig. 1: Innovative technologies for natural product drug discovery (Thomford et al., 2018). 
Molecular libraries of lead compounds from natural products $R \& D$ will serve as sources of lead compounds/herbal tinctures for innovative drugs. In the application of innovative technologies combined with systems biology, the focus should not be a reductionist approach of trying to source a single active compound but to consider the synergistic effects of compounds. It is important to emphasize that innovative drug discovery from natural products will require a nonreductionist strategy to understand their complex mechanisms of action at the molecular level (Thomford et al., 2018). Thus systems biology guided approach provides a different angle in natural products pharmasciences. Hamdard Laboratories, Zandu Ayurveda, Patanjali Ayurveda, Himalaya Wellness, Baidyanath are some top herbal pharmaceuticals companies of India.

\section{Future perspective}

Medicinal plants should be considered as metaorganisms that comprise both the plant themselves and their microbiome. As meta-organisms, they are a largely untapped and enormous bioresources for bioactive compounds and microorganisms of potential use not only in biocontrol but also used in modern medicine, agriculture, and pharmaceutical industry. As such, more research is necessary to exploit this immense reservoir for mankind.

Fewer studies had been quoted on medicinal plants and microbial interaction drive secondary metabolites. These metabolites have unique characteristics which make them an important candidate for discovery of new drugs and lead molecules. So far the major lacuna in the area of plant metabolite research is the identification and scientific validation of the secondary metabolite and their biosynthetic mechanism with an upsurge in the demand for phytocompounds, the advanced sequencing technologies such as transcriptomic data, metabolomics and proteomics study in combination with computational biology for faster research and better molecular characterization of natural products.

\section{Conflict of interest statement}

Authors declare that they have no conflict of interest.

\section{References}

Abdou, R., Scherlach, K., Dahse, H. M., Sattler, I., Hertweck, C., 2010. Botryorhodines A-D, antifungal and cytotoxic depsidones from Botryosphaeria rhodina, an endophyte of the medicinal plant Bidens pilosa. Phytochemistry, 71: 110-116.

Abdullah, A. T., Hanafy, M. S., Eo-El-G, Ali, Z. H., 2012. Effect of compost and some biofertilizers on growth, yield, essential oil, productivity and chemical composition of Rosmarinus officinalis $\mathrm{L}$. plants. J. Hortic. Sci. Ornamental Plant, 4(2): 201214.

Abo-Elyousr, K. A. M., Sobhy, A. H., Abdel-Rahim, I. R., 2014. Isolation of Trichoderma and evaluation of their antagonistic potential against Alternaria porri. J. Phytpathol., 162: 567-574.

Aidemark, M., Tjellström, H., Sandelius, A. S., Stålbrand, H., Andreasson, E., Rasmusson, A. G., Widell, S., 2010. Trichoderma viride cellulase induces resistance to the antibiotic poreforming peptide alamethicin associated with changes in the plasma membrane lipid composition of tobacco BY2 cells. BMC Plant Biol., 10(1): 274.

Amna, T., Puri, S. C., Verma, V., Sharma, J. P., Khajuria, R. K., Musarrat, J., et al., 2006. Bioreactor studies on the endophytic fungus Entrophospora infrequens for the production of an anticancer alkaloid camptothecin. Can. J. Microbiol., 52: 189-196.

Arnold, P. A., Kruuk, L. E., Nicotra, A. B., 2019. How to analyse plant phenotypic plasticity in response to a changing climate. New Phytol., 222(3): 12351241.

Arshi, A., Abdin, M. Z., Iqbal, M., 2006. Sennoside content and yield attributes of Cassia angustifolia Vahl. as affected by $\mathrm{NaCl}$ and $\mathrm{CaCl}_{2}$. Scientia Hortic., 111(1): 84-90.

Ashraf, S., Zuhaib, M., 2014a. Fungal biodiversity a potential tool in plant disease management. In: Management of Microbial Resources in the Environment, (Eds.: Malik, A., Alves, M., Grohmann, E.), Springer, Dordrecht.

Ashraf, S., Zuhaib, M., 2014b. Efficacy of rhizospheric microorganism against wilt of Ashwagandha (Withania somnifera Dunal) and their influence on its growth. Trends in Biosci., 7(16): 2165-2167.

Bagnasco, P., De La Fuente, L., Gaultieri, G., Noya, F., Arias, A., 1998. Fluorescent Pseudomonas spp. as biocontrol agents against forage legume root pathogenic fungi. Soil Biol. Biochem., 30: $1317-$ 1322.

Baker, K. F., Cook, R. J., 1974. Biological control of plant pathogens. San Francisco: WH Freeman and 
Co., (Book, reprinted in 1982, Am Phytopathol Soc, St Paul, Minnesota), 433p.

Bandopadhyay, S., 2015. Effect of dual inoculation of plant growth promoting rhizobacteria on different non-leguminous plants under pot condition. Indian J. Microbiol. Res., 2(1): 20-26

Benítez, T., Rincón, A. M., Limón, M. C., Codón, A. C., 2004. Mecanismos de biocontrol de cepas de Trichoderma. Int. Microbiol., 7(4): 249-260.

Berg, G., Smalla, K., 2009. Plant species and soil type cooperatively shape the structure and function of microbial communities in the rhizosphere. FEMS Microb. Ecol., 68: 1-13.

Berg, G., Zachow, C., Cardinale, M., Müller, H., Ecology and human pathogenicity of plantassociated bacteria. In: Regulation of Biological Control Agents (Ed.: Ehlers, R. U.), Springer, Dordrecht, pp.175-189.

Berini, J. L., Brockman, S. A., Hegeman, A. D., Reich, P. B., Muthukrishnan, R., Montgomery, R. A., Forester, J. D., 2018. Combinations of abiotic factors differentially alter production of plant secondary metabolites in five woody plant species in the boreal-temperate transition zone. Front. Plant Sci., 9: 1257

Castillo, U., Harper, J. K., Strobel, G. A., Sears, J., Alesi, K., Ford, E., et al., 2003. Kakadumycins, novel antibiotics from Streptomyces sp. NRRL 30566, an endophyte of Grevillea pteridifolia. FEMS Microbiol. Lett. 224: 183-190.

Castillo U, Strobel G A, Ford E J, Hess W M, Porter H, Jensen J B, et al., Munumbicins, wide-spectrum antibiotics produced by Streptomyces NRRL 30562, endophytic on Kennedia nigriscans. Microbiology, 2002; 148:2675-2685.

Chet, I., Inbar, J., Hadar, I., 1997. Fungal antagonists and mycoparasites. The Mycota IV: Environmental and microbial relationships, Berlin: SpringerVerlag, pp.165-184.

Chetri, S. P. K., Sharma, K., Agrawal, V., 2013. Genetic diversity analysis and screening of high psoralen yielding chemotype of Psoralea corylifolia from different regions of India employing HPLC and RAPD marker. Int. J. Plant Res., 26: 88-95.

Cook, R. J., Baker, K. F. 1983. The nature and practices of biological control of plant pathogen (p. 539). St. Paul: American Phytopathology Society.

Damam M, Gaddam B, Kausar R., 2014. Effect of plant growth promoting rhizobacteria (PGPR) on Coleus forskohlii. Int J. Curr. Microbiol. Appl. Sci., 3(9): 266-274.
Das I, Singh A P., 2014. Effect of PGPR and organic manures on soil properties of organically cultivated mungbean. Bioscan, 9(1):27-29

Debbab A, Aly A H, Edrada-Ebel R A, Müller W E, Mosaddak M, Hakiki A, et al., 2009. Bioactive secondary metabolites from the endophytic fungus Chaetomium sp. isolated from Salvia officinalis growing in Morocco. Biotechnol. Agron. Soc. Environ., 13:229-234

Dubey S C, Suresh M, Singh, B., 2007 Evaluation of Trichoderma species against Fusarium oxysporum $\mathrm{f}$. sp. ciceris for integrated management of chickpea wilt. J. Biol. Control, 40: 118-127.

Earanna N. V., 2001. A mycorrhizal association in medicinal plants of South Eastern dry zone of Karnataka and response of Phyllanthus amarus and Withania somnifera to inoculation with VAM fungi and plant growth promoting Rhizomicro-organisms. University of Agricultural Sciences, GKVK, Bangalore.

Earanna, N., 2001. VA mycorrhizal association in medicinal plants of Southeastern dry zone of Karnataka and response of Phyllanthus amarus and Withania somnifera to inoculation with VAM fungi and plant growth promoting rhizomicroorganisms. $\mathrm{Ph} . \mathrm{D}$ thesis. Submitted to University of Agricultural Sciences, Bangalore.

Edreva A, Velikova V, Tsonev T, et al., 2008. Stressprotective role of secondary metabolites: diversity of functions and mechanisms. Gen Appl Plant Physiol., 34(1-2): 67-78.

Ezra D, Castillo U F, Strobel G A, Hess W M, Porter H, Jensen J B, et al., 2004. Coronamycins, peptide antibiotics produced by a verticillate Streptomyces sp. (MSU-2110) endophytic on Monstera sp. Microbiology, 150: 785-79

Feng J C, Zhang Y J, Yang T-Z., 2002. Effect of lowtemperature stress on membrane lipid peroxidation and concentration of free-proline in Camptotheca acuminata seedling. For Res. 15(2):197-202

Gao K, Liu X, Guo R, Huai W, Zhang M., 2001. Study on the antagonism of Trichoderma species on canker pathogen fungi of popular. Scientia Silvae Sinicae, 37(5), 82-86.

Glass A D M, Britto D T, Kaiser B N, Kinghorn J R, Kronzucker H J, Kumar A, et al., 2002. The regulation of nitrate and ammonium transport systems in plants. J. Exp. Bot., 53:855-864.

Goulard, C., Hlimi, S., Rebuffat, S., Bodo, B., Trichorzins H A., 1995. antibiotic peptides from Trichoderma harzianum, I: Fermentation, isolation 
and biological properties. J. Antibiotics, 48: 12481253.

Handelsman J, Stabb E V., 1996. Biocontrol of soilborne plant pathogens. Plant Cell, 8(10): 1855.

Harman G E, Howell C R, Viterbo A, Chet I, Lorito M., 2004. Trichoderma species opportunistic, avirulent plant symbionts. Nature Rev. Microbiol., 2: 43-56

Harman G E. Overview of mechanisms and uses of Trichoderma spp. Phytopathology, 2006; 96(2), 190-194.

Harper J K, Arif A M, Ford E J, Strobel G. A., Porco J A, Tomer D P et al., 2003. Pestacin: a 1,3-dihydro isobenzofuran from Pestalotiopsis microspora possessing antioxidant and antimycotic activities. Tetrahedron, 59: 2471-2476

Hassan E, Tayebeh R, Samaneh E T., 2008. Quantification of Valerenic acid and its derivatives in some species of Valeriana $\mathrm{L}$ and Centranthus longiflorus Stev. Asian J Plant Sci., 7(2): 195-200.

Hemashenpagam N, Selvaraj T., 2011. Effect of arbuscular mycorrhizal (AM) fungus and plant growth promoting rhizomicroorganisms (PGPR's) on medicinal plant Solanum viarum seedlings. J. Environ. Biol., 32: 579-583.

Howell, C. R., Stipanovic, R. D., 1983. Gliovirin, a new antibiotic from Gliocladium virens, and its role in the biological control of Pythium ultimum. Can. J. Microbiol., 29(3): 321-324.

Immaculate N R, Kumar M, Srimathi S, Muthumary J, Kalaichelvan P T., 2011. Isolation of Phoma species from Aloe vera: an endophyte and screening the fungus for taxol production. World J. Sci. Technol., 1: $23-31$.

Jayalakshmi S K, Raju S, Rani S U, Benagi V I, Sreeramulu K., 2009. Trichoderma harzianum L sub 1 as a potential source for lytic enzymes and elicitor of defense responses in chickpea (Cicer arietinum L.) against wilt disease caused by Fusarium oxysporum f. sp. ciceri. Austr. J. Crop Sci., 3(1), 44-52.

Jeong H, Lee S H, Yun H S, Choi S R. Changes in allicin contents of garlic via light irradiation. Korean J Food Preserv. 2013;20(1):81-7.

Johri, B. N., Sharma, A., Virdi, J. S., 2003. Rhizobacterial diversity in India and its influence on soil and plant health. In: Biotechnology in India, Berlin/Heidelberg: Springer, pp. 49-89.

Kaur, R., Macleod, J., Foley, W., Nayudu, M., 2006. Gluconic acid: An antifungal agent produced by Pseudomonas species in biological control of takeall. Phytochemistry, 67: 595-604.
Kaymak H C, Yarali F, Guvenc I, Figen D M. The effect of inoculation with plant growth rhizobacteria (PGPR) on root formation of mint (Mentha piperita L.) cuttings. Afr J Biotech, 2008; 7(24): 4479-4483.

Kim S U, Strobel G A, Ford E. Screening of taxolproducing endophytic fungi from Ginkgo biloba and Taxus cuspidata in Korea. Agric. Chem. Biotechnol, 1999; 42: 97-99.

Köberl M, Schmidt R, Ramadan E M, Bauer R, \& Berg G. The microbiome of medicinal plants: Diversity and importance for plant growth, quality, and health. Front. Microbiol., 2013; doi.org/10.3389/fmicb.2013.0040

Komatsu, M. (1968). Trichoderma viride as an antagonist of wood inhabiting Hymenomycetes, VIII. The antibiotic activity against the Mycelial growth of Lentinus edodes (Berk) sig, of three genera $T$. pachybasium, Gliocladium and other sterile forms. Japan: Tottori Mycological Institute, pp.345-456

Kroymann J. Natural diversity and adaptation in plant secondary metabolism. Current Opin. Plant Biol.,.2011; 14(3): 246-51.

Kumar S, Gupta P, Sharma S, \& Kumar, D. A review on immunostimulatory plants. J. Chin. Integrative Med., 2011;9, 117-128

Kumara P M, Srimany A, Arunan S, et al., Desorption electrospray ionization (DESI) mass spectrometric imaging of the distribution of rohitukine in the seedling of Dysoxylum binectariferum Hook. F. PloS One, 2016; 11(6)

Kusari S, Lamshoft M, and Spiteller M. Aspergillus fumigatus Fresenius, an endophytic fungus from Juniperus communis L. Horstmann as a novel source of the anticancer pro-drug deoxypodophyllotoxin. J. Appl. Microbiol., 2009a; 107:1019-1030.

Kusari S., Zühlke S., Spiteller M. (2009b). An endophytic fungus from Camptotheca acuminata that produces camptothecin and analogues. J. Nat. Prod., 2009b; 72-78.

Latha, P, Anand T, Ragupathi N, Prakasam, V, and Samiyappan, R. Antimicrobial activity of plant extracts and induction of systemic resistance in tomato plants by mixtures of PGPR strains and Zimmu leaf extract against Alternaria solani. Biol. Control, 2009; 50, 85-93.

Lee J C, Lobkovsky E, Pliam N B, Strobel G, Clardy J. Subglutinols A and B: immunosuppressive compounds from the endophytic fungus Fusarium subglutinans. J. Org. Chem. 1995; 60: 7076-7077. 
Li R W, Myers S P, Leach D N, Lin G D, and Leach G. A cross-cultural study: anti-inflammatory activity of Australian and Chinese plants. J. Ethnopharmacol, 2003; 85:25-32.

Lucci N, Mazzafera P. Distribution of rutin in fava d'anta (Dimorphandra mollis) seedlings under stress. J Plant Interact, 2009; 4(3):203-8.

Lucy, M., Reed, E., \& Glick, B. R. Application of free living plant growth promoting rhizobacteria. Antonie Van Leeuwenhoek, 2004; 86, 1-25.

Mantelin S, Touraine B. Plant growth-promoting bacteria and nitrate availability: impacts on root development and nitrate uptake. J Exp Bot,2004; 55:27-34

McAlees, A. J., \& Taylor, A. The biodegradation of Ltyrosine by Trichoderma hamatum to trichoviridin and related compounds. Proceedings of the Nova Scotian Institute of Science, 1995;40(2), 61-65.

Miller K I, Qing C, Sze D M, and Neilan B A. Investigation of the biosynthetic potential of endophytes in traditional Chinese anticancer herbs. PLoS One, 2012a; doi.org/10.1371/journal.pone. 0035953

Miller K I, Qing C, Sze D M, Roufogalis B D, and Neilan B A. Culturable endophytes of medicinal plants and the genetic basis for their bioactivity. Microb. Ecol, 2012b; 64: 431-449.

Misra P, Maji D, Awasthi A, Pandey S S, Yadav A, Pandey A et al., Vulnerability of Soil Microbiome to Monocropping of Medicinal and Aromatic Plants and Its Restoration Through Intercropping and Organic Amendments. Front. Microbiol, 2019; 10:1-15

Mukerji, K. G., 2000. Exploitation of protoplast fusion technology in improving biocontrol potential. InBiocontrol potential and its exploitation in Sustainable agriculture (pp. 39-48). Boston: Springer.

Ncube B, van Staden J. Tilting plant metabolism for improved metabolite biosynthesis and enhanced human benefit. Molecules, 2015; 20(7):12698-731

Newman D J and Cragg G M. Natural products as sources of new drugs over the 30 years from 1981 to 2010. J. Nat. Prod., 2012; 75:311-335.

Ordookhani K, Sharafzadeh S H, Zare M. Influence of PGPR on growth, essential oil and nutrients uptake of sweet basil. Adv Environ Biol., 2011; 5(4):672677

Parewa H P, Yadav J, Rakshit A. Effect of fertilizer levels, FYM and bioinoculants on soil properties in inceptisol of Varanasi, Uttar Pradesh, India. Int J
Agric Environ Biotech, 2014a; 7(3): 517-525

Phuwapraisirisan, P., Rangsan, J., Siripong, P., \& TinPyang, S. 9-epiViridiol, a novel cytotoxic furanosteroid from soil fungus Trichoderma virens. Natural Prod. Res., 2006; 20(14), 1321-1325.

Plengmuankhae $\mathrm{W}$, Tantitadapitak C. Low temperature and water dehydration increase the levels of asiaticoside and madecassoside in Centella asiatica (L.) Urban. South Afr J Bot, 2015; 97: 196-203.

Polturak G, Aharoni A. "La Vie En Rose":biosynthesis, sources, and applications of betalain pigments. Mol Plant, 2018;11(1):7-22.

Puri S C, Verma V, Amna T, Qazi G N and Spiteller M. An endophytic fungus from Nothapodytes foetida that produces camptothecin. J. Nat. Prod., 2005; 68: 1717-1719.

Rachid, D., Ahmed, B. Effect of iron and growth inhibitors on siderophores production by Pseudomonas fluorescens. Afr. J. Biotechnol., 2005 4, 697-702

Rajasekar S, Elango R. Effect of microbial consortium on plant growth and improvement of alkaloid content in Withania somnifera (Ashwagandha). Curr. Bot., 2011; 2(8): 27-30.

Ramakrishna A, Ravishankar G A. Influences of abiotic stress signals on secondary metabolites in plants. Plant Signal Behav. $2011 ; 6(11): 1720-31$.

Saravanan R, Khristi S, Gajbhiye N A, Maiti S. Effect of plant population and soil moisture stress on herbage yield and andrographolide content in Andrographis paniculata. Indian J Hortic. 2009; 66(1):120-5.

Scher F M, \& Baker R. Effect of Pseudomonas putida and a synthetic iron chelator on induction of soil suppressiveness to Fusarium wilt pathogen. Phytopathology, 1982;72, 1567-1573

Schoonbeek, H., Raaijmakers, J. M., \& De Waard, M. A. Fungal ABC transporters and microbial interactions in natural environments. Molecular Plant-Microbe Interactions, 2002, 15, 1165-1172.

Selvaraj T, Rajeshkumar S, Nisha M C, Wondimu L, Tesso M. Effect of Glomus mosseae and plant growth promoting rhizomicroorganisms (PGPR's) on growth, nutrients and content of secondary metabolites in Begonia malabarica Lam. Maejo Int J Sci Technol, 2008; 2: 516-525.

Shahverdi M A, Omidi H, Tabatabaei S J. Stevia (Stevia rebaudiana Bertoni) responses to $\mathrm{NaCl}$ stress: growth, photosynthetic pigments, diterpene glycosides and ion content in root and shoot. $\mathrm{J}$ Saudi Soc Agric Sci., 2017 1:1. 
Sharma $\mathrm{P}$ and Trivedi $\mathrm{P}$ C. Evaluation of different fungal antagonists against Fusarium oxysporum infecting Withania somnifera (L.) Dunal. Biol. Environ. Sci., 2010; 6, 37-41.

Sharma P K, Gothalwal R. Changes in Perceptions Derived From Research on Trichoderma Species. Microbial Services in Restoration Ecology, 2020; 181-190

Sharma P K, Gothalwal R. Trichoderma based granular formulation for control of root diseases crops. Int. J. Plant Protect. 2010; 3:191-19

Siddiqui, Z. A. PGPR: Prospective biocontrol agents of plant pathogens. In Z. A. Siddiqui (Ed.), PGPR: Biocontrol and biofertilization 2006(pp. 111-142). Dordrecht: Springer.

Sriram S, Manasa S B, \& Savitha M J. Potential use of elicitors from Trichoderma in induced systemic resistance for the management of Phytophthora capsici in red pepper. Journal of Biological Control, 2009; 23,449-456.

Srivastava S, Srivastava M. Morphological changes and antioxidant activity of Stevia rebaudiana under water stress. Am J Plant Sci. 2014; 5(22): 3417-22.

Stierle A, Strobel G, and Stierle D. Taxol and taxane production by Taxomyces andreanae, an endophytic fungus of Pacific yew. Science, 1993; 260, 214216.

Strashnov, Y., Elad, Y., Sivan, A., Rerdick, Y., \& Chet, I. Control of Rhizoctonia solani fruit rot of tomatoes by Trichoderma harzianum Rifai. Crop Protection, 1985; 4, 359-336.

Strobel G, Daisy B. Bioprospecting for microbial endophytes and their natural products. Microbiol. Mol. Biol. Rev. 2003;67;491-502.

Strobel G, Ford E, Worapong J, Harper J K, Arif A M, Grant D M, et al., Isopestacin, an isobenzofuranone from Pestalotiopsis microspora, possessing antifungal and antioxidant activities. Phytochemistry, 2002; 60; 179-183.

Strobel G, Li J Y, Sugawara F, Koshino H, Harper J, and Hess W M. Oocydin A, a chlorinated macrocyclic lactone with potent anti-oomycete activity from Serratia marcescens. Microbiology, 1999a; 145, 3557-3564.

Strobel G, Miller R V, Martinez-Miller C, Condron M M, Teplow D B, and Hess W M. Cryptocandin, a potent antimycotic from the endophytic fungus Cryptosporiopsis cf. quercina. Microbiology, 1 999b; 145, 1919-1926

Sun SQ, Yan SF. Effects of nitrogen forms on camptothecin content and its metabolism-related enzymes activities in Camptotheca acuminata seedlings. China J Chin Mater Med, 2008; 33(3):1519-23

Suzuki, S., He, Y., \& Oyaizu, H. Indole-3-Acetic acid production in Pseudomonas fluorescens HP72 and its association with suppression of creeping bentgrass brown patch. Current Microbiology,2003 47(2), 138-143.

Szabo B, Tyihak E, Szabo G, Botz L. Mycotoxin and drought stress induced change of alkaloid content of Papaver somniferum plantlets. Acta Bot Hung. 2003;45(3):409-17

Thomashow, S. L., \& Weller, M. D. Role of antibiotics and siderophore in biocontrol of take-all disease of wheat. Plant and Soil, 1990 129, 95-99

Thomford N E, Senthebane D A, Rowe A, Munro D, Seele P, Maroyi A and Dzobo K. Natural Products for Drug Discovery in the 21st Century: Innovations for Novel Drug Discovery. Int $\mathrm{J}$ Mol Sci, 2018;19(6) 1578

Vashisth D, Kumar R, Rastogi S, et al., Transcriptome changes induced by abiotic stresses in Artemisia апnиа. Sci Rep. 2018; 8(1):3423

Vinale F, Sivasithamparam K, Emilio L, Wool L, Nigro M, Marra R, Lombardi N, Pascale A, Ruocco, M., Lanzuise, S, Manganiello, G., \& Lorito, M. Trichoderma secondary metabolites active on plants and fungal pathogens. Open Mycol. J., 2014; 8: 127-139

Vinale F, Sivasithamparam K, Ghisalberti E L, Marra R, Woo S L, \& Lorito, M. Trichoderma - Plant pathogens interactions. Soil Biology and Biochemistry, 2008;40, 1-10

Wang J W, Zhang Z, and Tan R X. Stimulation of artemisinin production in Artemisia annua hairy roots by the elicitor from the endophytic Colletotrichum sp. Biotechnol. Lett., 2001; 23, 857860.

Wani M C, Taylor H L, Wall M E, Coggon P, and McPhail A T. Plant antitumor agents. VI. The isolation and structure of taxol, a novel antileukemic and antitumor agent from Taxus brevifolia. J. Am. Chem. Soc. 1971; 93, 2325-2327.

Weller, D. M.. Biological control of soilborne plant pathogens in the Rhizosphere with bacteria. Ann. Rev. Phytopathol., 1988, 26(1): 379-407.

Whistler, C. A., Stockwell, V. O., Loper, J. E.. Lon protease influences antibiotic production and UV tolerance of Pseudomonas fluorescens Pf-5. Appl. Environ. Microbiol., 2000, 66: 2718-2725.

Wings, S., Müller, H., Berg G., Lamshöft,M., Leistner 
E., 2013.A study of the bacterial community in the root system of the maytansine containing plant Putterlickia verrucosa. Phytochemistry. 91,158-164

Yang L, Wen K S, Ruan X, Zhao Y X, Wei F, Wang Q., 2018. Response of plant secondary metabolites to environmental factors. Molecules, 23(4): E762.

Yang X, Guo S, Zhang L, and Shao H., 2003. Selection of producing podophyllotoxin endophytic fungi from podophyllin plant. Nat. Prod. Res. Dev., 15: 419-422.

Zafari, D., Koushki, M. M., Bazgir, E., 2008. Biocontrol evaluation of wheat take-all disease by Trichoderma screened isolates. Afr. J. Biotechnol., 7(20): 36533659.

Zeng J, Chen A, Li D, Yi B, Wu W., 2013. Effects of salt stress on the growth, physiological responses, and glycoside contents of Stevia rebaudiana Bertoni. J. Agric. Food Chem., 61(24): 5720-5726.

Zhu W, Yang B, Komatsu S, Lu X, Li X, Tian J., 2015.
Binary stress induces an increase in indole alkaloid biosynthesis in Catharanthus roseus. Front. Plant Sci., 6: 582.

Zhu Z, Liang Z, Han R, Wang X., 2009. Impact of fertilization on drought response in the medicinal herb Bupleurum chinense DC.: growth and saikosaponin production. Ind. Crops Prod., 29(2-3): 629-33.

Zimand G, Elad Y, Chet I., 1996. Effect of Trichoderma harzianum on Botrytis cinerea pathogenicity. Phytopathol., 86(11): 1255-1260.

Zou W X, Meng J C, Lu H, Chen G X, Shi G X, Zhang $\mathrm{T}$ Y, et al., 2000. Metabolites of Colletotrichum gloeosporioides, an endophytic fungus in Artemisia mongolica. J. Nat. Prod., 63: 1529-1530.

Zykin P A, Andreeva E A, Lykholay A N, Tsvetkova N V, Voylokov A V., 2018. Anthocyanin composition and content in rye plants with different grain color. Molecules, 23: 948.

\section{How to cite this article:}

Rizwan, R., Gothalwal, R., 2021. Microbiomes of medicinal plants and their potential avenues as bioresources - A review. Int. J. Curr. Res. Biosci. Plant Biol., 8(11): 29-40. doi: https://doi.org/10.20546/ijcrbp.2021.811.004 